\title{
The Research Framework Model of Rapid Assessment and Emergency Plan Selection for Urban Flood Disaster
}

\author{
Junai Yan, Yuanyuan Fan, Shuwei Jing \\ School of Management Science and Engineering, Shanxi University of Finance \& Economics, Taiyuan, China \\ Email: sxyja@126.com
}

How to cite this paper: Yan, J.A., Fan, Y.Y. and Jing, S.W. (2017) The Research Framework Model of Rapid Assessment and Emergency Plan Selection for Urban Flood Disaster. World Journal of Engineering and Technology, 5, 103-108. https://doi.org/10.4236/wjet.2017.53B012

Received: July 20, 2017

Accepted: August 8, 2017

Published: August 11, 2017

\begin{abstract}
Given that it is difficult to assess the harmfulness and make emergency response timely in the early stage when flood disasters happen in cities for that the data are complex and rapidly changing, this article constructs a rapid assessment model, namely Simple Simos Procedure and PROMTHEE II Model (SSPPM), to assess the severity of flood disaster occurring in cities at the early stage based on a view of the rapid flood disaster assessment. On this basis, the fuzzy VIKOR method is applied to choose a scientific emergency plan. This article aims to construct a research framework model, which can provide some practice implications to reduce the losses caused by flood disaster.
\end{abstract}

\section{Keywords}

Flood Disaster, Rapid Assessment, Emergency Plan

\section{Introduction}

The statistical data from the Ministry of Civil Affairs and the National Disaster Reduction Committee show that, in China, the flood and geological disasters possess a high proportion among the natural disasters happened in the first quarter of 2017 (as shown in Figure 1).

Since June 3rd, 2017, there have been heavy rains in the mid-eastern China, such as the mid-west Hubei, the northeastern Sichuan, the mid-eastern Chongqing, the northwestern Hunan, and the eastern Guizhou. The rainfall in Wuxi, Tongren and other areas reached 200 to $269 \mathrm{~mm}$. And on June 4th, the rainfall of some areas in Yanhe County, Tongren reached $203 \mathrm{~mm}$, where the maximum hourly rainfall is 60 to $96 \mathrm{~mm}$. The villages in Jiangxi, Hubei, Hunan, Chongqing, Sichuan, Guizhou and so on were flooded because of the heavy rainfall. As a 


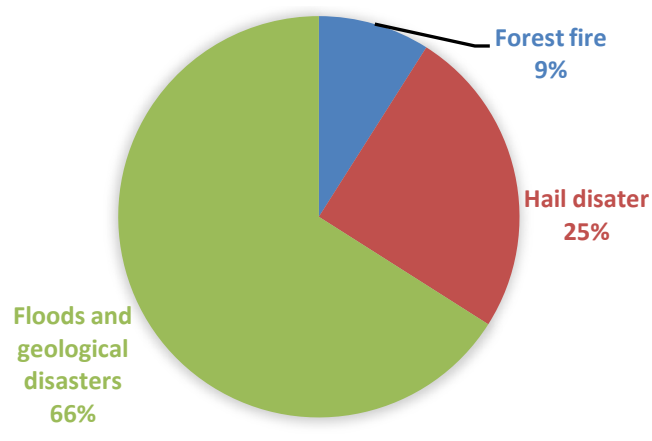

Figure 1. The proportion of natural disasters in the first quarter of 2017 in China.

result, the paddy field was flooded, and some of the farmhouses collapsed. According to the statistics, 292 thousands of people were affected by the flood disaster, and more than 2300 people were evacuated and nearly 1400 people need emergency assistance among the above the six provinces (municipalities), 22 cities, autonomous counties and 51 counties (cities, districts). The area size of crop affected by flood reached 11.9 thousand hectare; more than 400 houses collapsed, and nearly 4200 houses were damaged to varying degrees. The direct economic losses accounted to 130 million yuan.

Thus it can be seen that the occurrence of flood disaster will not only cause huge losses to the economy and crops in cities, but also cause the tremendous destruction to residents which cannot be recovered in a short time. Meanwhile it will bring a heavy financial burden to the government. The statistical data of typical urban flood of 2013-2016 in China are shown in Table 1.

Generally, cities are political, cultural and economical center and trafficing hub, which play a pivotal role in the whole national economy. Once the cities are suffered from flood disaster, the losses and hazards are more serious than those in other areas, which also will affect the economic development and social development process of local cities seriously for a long period of time.

Obviously, the flood disaster has become a great potential danger to the rapid development of urban economy. Affected by the uncertainties of the weather and the city's self-factors, we cannot predict the flood disaster accurately. Coupled with that flood disaster has a wide influence scope and spreads quickly, it is bound to cause serious damage to cities if we don't deal with flood disasters scientifically and rapidly at the beginning. So, it is quite urgent and necessary for us to process this research to help to restore social order, maintain social stability and minimize the lives and property loss in the shortest time.

\section{Literature Review}

The academic community has been concerned about the flood disaster and its emergency response research. Existing literature have also done research on the flood disaster. Through carding analysis, we can see that the rapid assessment of 
Table 1. 2013-2016 typical urban flood disaster loss statistics table.

\begin{tabular}{|c|c|c|c|c|c|c|c|}
\hline \multirow[b]{2}{*}{ Year } & \multirow[b]{2}{*}{ The affected city } & \multicolumn{3}{|c|}{ Population affected } & \multicolumn{3}{|c|}{ Losses } \\
\hline & & $\begin{array}{c}\text { The affected } \\
\text { population (million) }\end{array}$ & $\begin{array}{l}\text { Emergency transfer } \\
\text { population (million) }\end{array}$ & Death (person) & $\begin{array}{c}\text { Direct economic } \\
\text { loss (billion) }\end{array}$ & $\begin{array}{c}\text { Collapsed } \\
\text { house (room) }\end{array}$ & $\begin{array}{c}\text { Damaged area of } \\
\text { crops } \\
\text { (hectare) }\end{array}$ \\
\hline 2016 & Wuhan & 75.7 & 16.7897 & 14 & 22.65 & 5848 & 97,404 \\
\hline \multirow{2}{*}{2015} & $\begin{array}{c}\text { Fujian, Jiangxi, } \\
\text { Hunan, } \\
\text { Guangxi, Guizhou }\end{array}$ & 6794 & 238.3 & 355 & 632.6 & 7300 & 48,300 \\
\hline & $\begin{array}{c}\text { Northeastern } \\
\text { Jiangxi and } \\
\text { Northern Fujian }\end{array}$ & 20.1 & 80.7 & 42 & 7.5 & 4000 & 23,000 \\
\hline 2014 & Chongqing & 212.2 & 9.2 & 42 & 26.2 & 32,000 & 41,000 \\
\hline 2013 & $\begin{array}{l}\text { Liaoning, Jilin, } \\
\text { Heilongjiang }\end{array}$ & 373.7 & 15.9 & 58 & 0.78 & 1300 & 18,010 \\
\hline
\end{tabular}

disaster and the emergency response program mainly focus on the following two aspects:

1) Research on rapid assessment, including flood and other disasters damage assessment. a) Research on flood losses, such as economic losses caused by flood, loss of personnel, earthquake victims, loss of disaster chains and loss of typhoon disasters [1]. b) The research on the types of disasters is mainly focused on earthquake disasters and its secondary disasters, typhoons, landslides and post-disaster rescue assessment and so on [2] [3]. Some scholars based on disaster relief agencies and venues for rapid post-disaster assessment provide a scientific basis and theoretical guidance for emergency response [4].

2) Research on the selection of emergency plan. a) The theoretical level. Analyzing the emergency response plan from the view of implementation effect, model driven and establish the rapid response model. There are also scholars putting forward emergency plan from the perspective of synergies, similar cases, response scenarios between emergency response departments and so on. b) Technical method level. Applying "Internet plus" technology in the construction of sudden incident rapid response system, which is a breakthrough that make the emergency response program achieve large data in recent years. This also provides a possibility for emergency management departments to build a rapid response system. There are also some literatures studying the choice of emergency response plan based on decision-makers' psychological behavior, loss and disappointment avoidance behavior prospect theory model and rescue cost. In addition, some literature adopts quantitative methods such as EA, FAHP and FTOPSIS, hierarchical task grid and similarity calculation to choose emergency plan. c) The content level, mainly study the emergency plan of maritime emergencies, ship oil spill accident, forest fire, the crowd gathered incident, construction accident of hydropower project and natural gas pipeline accident etc. [5] [6] [7] [8].

3) Thus, most existing literature has been assessed disaster losses, earthquake disasters and their secondary disasters quickly, but few scholars have made rapid 
assessments for flood disaster at the very beginning. And most researches on emergency plan are aimed at fires and earthquakes, and the amount of researches on the emergency response plan selection aimed at flood disaster is relatively small. In addition, the existing selection methods also have some shortcomings, on the one hand, the methods are chosen from a single aspect which lacks comprehensiveness. On the other hand, it ignores the psychological expectations of different decision makers, which causes that the chosen emergency plan lacks scientificity and rationality. However, the VIKOR method can exactly solve the above problems precisely, and put the maximum benefits for different decision-makers into consideration to select a relatively reasonable emergency plan [9]. First, confirm that you have the correct template for your paper size. This template has been tailored for output on the custom paper size $(21 \mathrm{~cm} \times$ $28.5 \mathrm{~cm}$ ).

\section{Research Process and Methods}

In order to solve the problem of rapid assessment for flood disaster and emergency plan choosing, the research frame is designed as follows:

1) Construct a grade evaluation index system for flood disaster. On the basis of the existing research results, we analyze the influencing factors of flood disaster grade and constructing the evaluation index system, then use the factor analysis method to simplify and reduce the evaluation index. Finally, we process index dimensionless adopting the extreme method.

2) Establish a rapid assessment model for flood disaster [10]. On the basis of constructing the evaluation index system, this article discusses the principle of model construction firstly; Secondly, it builds a model which mainly includes the following procedures: a) Introduce the methods on model construction, including the method of weight coefficient (Simos method) and disaster ranking method (Promethee II method), and then construct the evaluation index system; b) Analyze the rapid assessment process briefly, such as collecting disaster realtime data during the preparatory phase, and then invite the experts on emergency decision-making to process the disaster data and assess the flood disaster rapidly and synthetically.

3) The choice of emergency response plan for flood disaster. Firstly, construct the evaluation index system based on the evaluation of the level of flood disaster. Secondly, introduce the utility weights to construct a fuzzy VIKOR method which can reflect the subjective preferences of decision-makers. Finally, conduct empirical analysis to choose the best solution that can be accepted by decision makers. The technical route is shown in Figure 2.

\section{Conclusion}

In order to solve the problems, such as the shortage and variability of data, and urgent rescue mission assignment at the early stage when the flood disaster occurs, this paper intends to accomplish the following two research objectives: 1) 


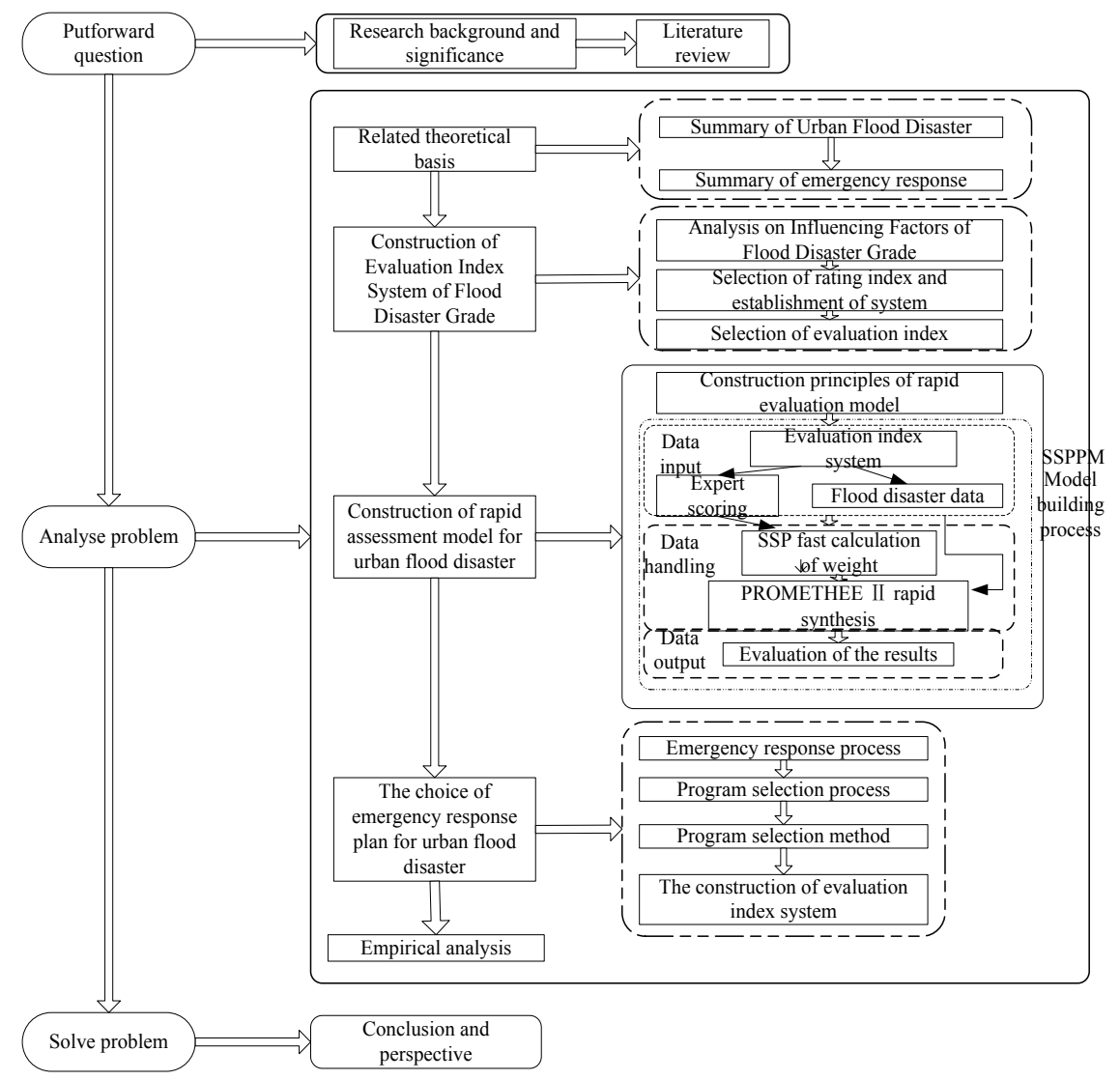

Figure 2. The map of technical route.

The construction of the SSPPM, a rapid assessment model of the urban flood disaster; 2) The choice of emergency plan. This article adopts the VIOKR way to select the highest comprehensive score scheme for flood disaster rescue aiming at the rescue departments of different inputs and outputs.

In this article, the rapid assessment model can be used to evaluate the flood disaster scientifically and rapidly in time, and we can use the VIKOR method to select a practical emergency response program from the existing scheme according to the evaluation result in a short time, which helps to reduce the severity of losses caused by the sudden flood disaster effectively. This article will also improve the urban flood disaster emergency response theory to a certain extent. Aimed at reducing the loss of urban flood disaster, this article uses SSPPM model to assess other emergencies quickly, including the grade of earthquake, the degree of fire and the influence of infectious diseases etc. Meanwhile, it can also provide references for solving a variety of unexpected incidents in real life.

\section{Acknowledgements}

I have received a lot of selfless help during my master's degree, and I would like to say "thank you" to all of you!

First of all, I want to thank my advisor, Professor Yan Junai, who has given me great instruction and great help both in my studies and in my life. 
Secondly, I would like to thank Mr. Yan's academic team and my graduate students who have taught me teamwork and independent thinking ability, especially thanks to Jing Shuwei's patient guidance!

Finally, I would like to pay tribute to all the distinguished scholars in the academic circles. Then, thank you again for your admission!

\section{References}

[1] Hu, H.B. and Zhang, Y.L. (2014) Quick Assessing Model on Casualty Loss in Rainstorms. Journal of Catastrophology, 29, 30-36.

[2] Ahamed, A., Bolten, J. and Doyle, C. (2016) Assessment of Flood Disaster Impacts in Cambodia: Implications for Rapid Disaster Response. EGU General Assembly Conference, EGU General Assembly Conference Abstracts, 152-158.

[3] Yury, K., Chen, H., Nick, O., et al. (2016) Rapid Assessment of Disaster Damage Using Social Media Activity. Science Advances, 2, 171-176.

[4] Balcik, B. (2017) Site Selection and Vehicle Routing for Post-Disaster Rapid Needs Assessment. Transportation Research Part E Logistics \& Transportation Review, 101, 30-58. https://doi.org/10.1016/j.tre.2017.01.002

[5] Liu, Y.X.Y. and Ji, M. (2015) Design and Implementation of the Ocean Oil Spill Emergency Response Decision Support System. Geomatics World, No. 3, 68-72.

[6] Jiang, X., Xu, P. and Zheng, X.Z. (2016) Study on Decision about Response Program to Emergencies in Hydropower Project Construction. China Safety Science Journal, No. 4, 161-167.

[7] Liu, R.T., Jiang, J.P., Shi, B., et al. (2017) Decision-Making Models of Dynamically Technology Preparedness Plan Production for Emergency Response to Chemical Spills in Surface Waters. Acta Scientiae Circumstantiae, 37, 763-770.

[8] Liang, X. and Jiang, Y.P. (2016) Method of Selecting Emergency Alternation Considering Loss Aversion and Disappointment Aversion Behaviors of Decision Maker. Systems Engineering, No. 9, 154-158.

[9] Rostamzadeh, R., Govindan, K., Esmaeili, A., et al. (2015) Application of Fuzzy VIKOR for Evaluation of Green Supply Chain Management Practices. Ecological Indicators, 49, 188-203. https://doi.org/10.1016/j.ecolind.2014.09.045

[10] Zhao, H.-J., Peng, Y., Li, J., et al. (2015) Emergency Incidents Rapid Comprehensive Assessment Model. System Engineering Theory and Practice, 35, 545-555. 
Submit or recommend next manuscript to SCIRP and we will provide best service for you:

Accepting pre-submission inquiries through Email, Facebook, LinkedIn, Twitter, etc. A wide selection of journals (inclusive of 9 subjects, more than 200 journals)

Providing 24-hour high-quality service

User-friendly online submission system

Fair and swift peer-review system

Efficient typesetting and proofreading procedure

Display of the result of downloads and visits, as well as the number of cited articles Maximum dissemination of your research work

Submit your manuscript at: http://papersubmission.scirp.org/

Or contact wjet@scirp.org 